\title{
Puerperal sepsis: predominant organisms and their antibiotic sensitivity pattern
}

\author{
Sabiha S. Tamboli ${ }^{1}$, Saleem B. Tamboli ${ }^{2}$, Sunanda Shrikhande ${ }^{1}$
}

${ }^{1}$ Department of Microbiology, Dr S C Govt Medical College, Nanded, Maharashtra, India
${ }^{2}$ Department of Pharmacology, Dr S C Govt Medical College, Nanded, Maharashtra, India

Received: 09 January 2016

Revised: 08 February 2016

Accepted: 09 February 2016

\section{*Correspondence:}

Dr. Sabiha Saleem Tamboli,

E-mail: microbiopharma@yahoo.com

Copyright: (C) the author(s), publisher and licensee Medip Academy. This is an open-access article distributed under the terms of the Creative Commons Attribution Non-Commercial License, which permits unrestricted non-commercial use, distribution, and reproduction in any medium, provided the original work is properly cited.

\begin{abstract}
Background: Puerperal sepsis is among the leading cause of preventable maternal morbidity and mortality not only in developing countries but in developed countries as well. This study was undertaken to isolate and identify aerobic bacterial agents of puerperal sepsis among the patients admitted in rural medical college of Maharashtra.

Methods: Blood samples were collected from 67 cases of Puerperal sepsis and were cultured aerobically. The organisms were identified by standard biochemical tests. Antimicrobial sensitivity testing done by Kirby Bauer disc diffusion method.

Results: Out of 67 samples, $46(68.65 \%)$ yielded growth in blood culture. The isolated organisms were Klebsiella aerogenes, Staph. aureus, Pseudomonas aeruginosa, Proteus, E. coli, Streptococcus pyogenes and coagulase negative Staphylococci. Most of the organisms are resistant to commonly used antibiotics such as ampicillin, penicillin and amikacin.

Conclusions: Puerperal sepsis is the common life threatening condition in the postnatal period, particularly following vaginal delivery. Early diagnosis and appropriate treatment of puerperal sepsis can make the difference between life and death.
\end{abstract}

Keywords: Puerperal sepsis, Antibiotic sensitivity, Maternal mortality

\section{INTRODUCTION}

Puerperal pyrexia and sepsis are among the leading causes of preventable maternal morbidity and mortality not only in developing countries but in developed countries as well. ${ }^{1}$ Maternal mortality ratio is a sensitive indicator of health status of women. ${ }^{2}$ puerperal sepsis occurs in $1-8 \%$ of all deliveries. It can occur following normal vaginal deliveries and of cesarean section. ${ }^{3}$ The worldwide increase in cesarean section rates has led to increased delivery complications. ${ }^{4}$

Puerperal sepsis contributes to a lot of maternal morbidity, more so in rural women. How often and for which of these complications postpartum women seek healthcare is not very well documented but need to be studied in depth as many of the complications can either be prevented or appropriately treated if detected early. The organisms which cause it include Staph. aureus, Strep. pyogenes, Coliform bacteria. $^{5}$

There are very few studies particularly on bacterial etiology of puerperal sepsis. It is known that bacterial pattern with their antimicrobial susceptibility is a dynamic and changing phenomenon and surveillance of this event is needed in every healthcare setting. The study was aimed to determine causative organisms and antibiotic susceptibility of the isolates. 


\section{METHODS}

The present study was undertaken for two years. Women admitted for puerperal sepsis after having delivered at home or at other hospitals or readmitted after discharge following delivery at the study hospital were included in study. A total of 67 patients were studied. Seventy five percent of the women seeking services at our hospital are rural belonging to lower and middle socioeconomic class. $10 \mathrm{ml}$ of blood was collected in Brain Heart Infusion Agar-Brain Heart Infusion Broth (BHIA-BHIB). Blood culture bottles were observed daily for signs of growth like turbidity, colonies over solid slant portion and subcultured onto solid media like blood agar and MacConkeys agar and evaluated after 24 hours, 48 hours and maximum upto 7 days before declaring it as negative. All laboratory methods followed standard protocols. The preliminary identification tests like catalase, oxidase, motility and coagulase etc. were done to ascertain in the identification of the pathogen. ${ }^{6}$ Antimicrobial sensitivity was done on Muller Hinton agar and blood agar depending on the nature of the isolate by Kirby Bauer disc diffusion method.

\section{RESULTS}

Table 1 shows age and parity of patients. Majority of women belongs to 20-29 years of age group.

Table 1: Age and parity.

\begin{tabular}{|lll|}
\hline Age (years) & parity & Number of cases \\
\hline$<19$ & 1 & 6 \\
\hline $20-29$ & 1 & 28 \\
\hline & 2 & 17 \\
\hline & $3-4$ & 9 \\
\hline $30-39$ & 2 & 3 \\
\hline & $3-4$ & 4 \\
\hline Total & & 67 \\
\hline
\end{tabular}

Table 2: Place and type of delivery.

\begin{tabular}{|lll|}
\hline Place & Type of delivery & Number of cases \\
\hline \multirow{2}{*}{$\begin{array}{l}\text { Study } \\
\text { hospital }\end{array}$} & Normal delivery & 17 \\
\cline { 2 - 3 } & Institutional V D & 6 \\
\cline { 2 - 3 } $\begin{array}{l}\text { Other } \\
\text { hospitals }\end{array}$ & Noesarean section & 2 \\
\cline { 2 - 3 } & Institutional V D & 5 \\
\cline { 2 - 3 } Home & Caesarean section & 3 \\
\hline Total & & 21 \\
\hline
\end{tabular}

V D- vaginal delivery

Table 3 shows various isolates. Sixty seven patients from Obstetric department were evaluated over a period of two years. Of them, 46 showed bacterial growth. Rests of the samples were sterile. Gram negative organisms were isolated in 31 cases $(67.39 \%)$ while Gram positive organisms in 15 cases $(32.60 \%)$. Klebsiella was the most frequent isolate13 (28.26\%) followed By Staph. aureus $10(21.73 \%)$.

Table 3: Isolates in blood culture.

\begin{tabular}{|lll|}
\hline Organisms isolated & Number & Percentage \\
\hline Kleb. aerogenesa & 13 & $28.26 \%$ \\
\hline Staph. aureus & 10 & $21.73 \%$ \\
\hline Pseudo. aeruginosa & 9 & $19.56 \%$ \\
\hline Proteus & 5 & $10.86 \%$ \\
\hline E. coli & 4 & $8.69 \%$ \\
\hline Strept. pyogenes & 3 & $6.52 \%$ \\
\hline Staph. albus & 2 & $4.34 \%$ \\
\hline Total & 46 & $68.65 \%$ \\
\hline
\end{tabular}

Table 4 shows antimicrobial sensitivity pattern of isolates. Most of the organisms are resistant to ampicillin, penicillin and amikacin.

Table 4: Antimicrobial susceptibility pattern of isolates.

\begin{tabular}{|lllllllll|}
\hline Isolates Antibiotics & $\begin{array}{l}\text { Klebsiella } \\
\text { aerogenes } \\
(\mathbf{n = 1 3})\end{array}$ & $\begin{array}{l}\text { Staph. } \\
\text { aureus } \\
(\mathbf{n = 1 0 )}\end{array}$ & $\begin{array}{l}\text { Pseudo. } \\
\text { aeruginosa } \\
(\mathbf{n = 9})\end{array}$ & $\begin{array}{l}\text { Proteus } \\
\text { species } \\
(\mathbf{n = 5})\end{array}$ & $\begin{array}{l}\text { E. } \\
\text { coli } \\
(\mathbf{n = 4})\end{array}$ & $\begin{array}{l}\text { Strep. } \\
\text { pyogenes } \\
(\mathbf{n = 3})\end{array}$ & $\begin{array}{l}\text { Staph. } \\
\text { allous } \\
(\mathbf{n = 2})\end{array}$ & $\begin{array}{l}\text { Total } \\
(\mathbf{n = 4 6})\end{array}$ \\
\hline Ampicillin & $4(30.76)$ & $1(10)$ & $5(55.55)$ & $1(20)$ & $0(0)$ & $1(33.33)$ & $1(50)$ & $13(28.26)$ \\
\hline Gentamicin & $11(84.61)$ & $8(80)$ & $6(66.66)$ & $3(60)$ & $2(50)$ & $2(66.66)$ & $1(50)$ & $33(71.73)$ \\
\hline Cotrimoxazole & $2(15.38)$ & $2(20)$ & $1(11.11)$ & $1(20)$ & $1(25)$ & $1(33.33)$ & $0(0)$ & $8(17.39)$ \\
\hline Ciprofloxacin & $12(92.30)$ & $7(70)$ & $8(88.88)$ & $5(100)$ & $3(75)$ & $3(100)$ & $2(100)$ & $38(82.60)$ \\
\hline Cephalexin & $4(30.76)$ & $10(100)$ & $5(55.55)$ & $2(40)$ & $1(25)$ & $3(100)$ & $2(100)$ & $23(50)$ \\
\hline Norfloxacin & $9(69.23)$ & $7(70)$ & $4(44.44)$ & $1(20)$ & $2(50)$ & $0(0)$ & $0(0)$ & $23(50)$ \\
\hline Amikacin & $8(61.53)$ & $7(70)$ & $5(55.55)$ & $4(80)$ & $2(50)$ & $2(66.66)$ & $1(50)$ & $29(63.04)$ \\
\hline Penicillin & $1(7.69)$ & $2(20)$ & $2(11.11)$ & $0(0)$ & $1(25)$ & $2(66.66)$ & $1(50)$ & $9(19.56)$ \\
\hline Erythromycin & $2(15.38)$ & $1(20)$ & $1(11.11)$ & $0(0)$ & $0(0)$ & $2(66.66)$ & $2(100)$ & $8(17.39)$ \\
\hline Polymyxin B & - & - & $7(77.77)$ & $1(20)$ & & & $8(17.39)$ \\
\hline Carbenicillin & - & - & $6(66.66)$ & $1(20)$ & & & 7 \\
\hline
\end{tabular}

Figures in the bracket represent percentage. 


\section{DISCUSSION}

Post partum morbidity continues to be major health issues which need to be looked into critically not only for curative but preventive and promotive health. It is being believed that in developing countries $65 \%$ of all women have some form of antenatal care and $53 \%$ intranatal care, only $30 \%$ receive postpartum care. A big proportion of Indian women still deliver at home with or without any prenatal and intranatal care. They are malnourished, anemic and remain prone to postpartum complications.

Out of all the women admitted in present study, six $(8.95 \%)$ were teenagers, $54(80.59 \%)$ between 20 and 29 years of age and seven (10.44\%) between 30 and 39 years. Majority of the women came from lower socioeconomic class. Majority of them were uniparous (50.74\%), $29.85 \%$ belonged to parity two, $19.40 \%$ to parity 3 or 4 (Table 1).

Of the 67 women, 21(31.34\%) has delivered at home, $21(31.34 \%)$ at other hospitals or private maternity homes and $25(37.31 \%)$ at the study hospital (Table 2).

It is important to understand the bacteriology of puerperal sepsis. Enhanced detection of blood stream infections needs to be a national priority. Blood culture is the essential investigation for the management of sepsis. In the present study, out of 67 cases studied, bacteremia was present in $46(68.65 \%)$ cases. The ratio of Gram positive to Gram negative organism was (2.06: 1$)$.

Present study shows predominance of Gram negative bacilli $(67.39 \%)$ with $32.60 \%$ isolates being Gram positive cocci. Similar findings reported by another study which showed isolation of Gram negative organism as $60 \%$ and Gram positive cocci as $40 \%$ from cases of puerperal sepsis. ${ }^{7}$ Distribution of bacteria as the cause of puerperal sepsis observed in the present study was in contrast to the other studies. They showed predominance of Gram positive cocci (78\%) with $8 \%$ isolates being Gram negative bacteria. ${ }^{8}$

Klebsiella and Staph. aureus were the major isolates in the present study. Other studies from India reported E.coli as the predominant pathogens followed by Staph. aureus and Klebsiella., ${ }^{9,10}$ Whereas Venugopal and Bhaskaran and Omu and Ajabor reported E. coli as the predominant pathogen in puerperal sepsis. ${ }^{11,12}$ Other organisms isolated in our study were Pseudomonas aeruginosa, Proteus, E. coli, Streptococcus pyogenes and coagulase negative Staphylococci in the descending order of their frequency. Other study found E. coli as the predominant bacteria (50\%) followed by Staphylococcus species $(30 \%)$ and Streptococcus species $(20 \%){ }^{13}$ Distribution of E. coli, Staphylococcus species and Streptococcus species in another study done in USA was reported to be $36 \%, 28 \%$ and $21 \%$ respectively. ${ }^{14}$
Another study observed that in cases of puerperal sepsis the most common bacteria were Staph. epidermidis, E. coli, Enterococci and streptococci. ${ }^{15}$ The frequency of puerperal infection due to Group A beta hemolytic Streptococci has decreased greatly in the 21 st century and now rarely caused maternal death. In the $18^{\text {th }}$ and $19^{\text {th }}$ centuries puerperal infection was a serious life threatening condition. ${ }^{16}$

In the present study, antimicrobial susceptibility of different bacterial isolates was seen. Kleb. aerogenes shows sensitivity to ciprofloxacin $(92.30 \%)$ and gentamicin (84.61\%), Pseudo. aeruginosa shows sensitivity to ciprofloxacin $(88.88 \%)$. Majority of the isolates of Proteus were sensitive to ciprofloxacin (100\%) and Amikacin (80\%). E. coli shows sensitivity to ciprofloxacin (75\%). Staph aureus shows sensitivity to cephalexin (100\%), gentamicin $(80 \%)$ and ciprofloxacin (70\%). Strep. Pyogenes was $100 \%$ sensitive to cephalexin and ciprofloxacin.

Others reported that majority of different Gram positive cocci shows sensitivity to cephalosporin. ${ }^{17}$ Another study from Nepal also observed that $100 \%$ strains of Gram positive cocci were sensitive to cephalexin. ${ }^{18}$ Finding of the two studies mentioned above were well consistent with results of the present study. In a study by Modi et al E. coli and other Gram negative bacteria showed $100 \%$ sensitivity to gentamicin which was not similar to our study. ${ }^{19}$ Sensitivity to ciprofloxacin among different bacteria as found in the present study was similar to Marten et al. ${ }^{20}$

\section{CONCLUSIONS}

Blood culture is still the 'Gold Standard' for the diagnosis of puerperal sepsis and should be done in all cases of suspected septicemia. In view of the changing spectrum of the causative agents of puerperal sepsis and their antibiotic sensitivity patterns from time to time and from one hospital to another, a positive blood culture and the antibiotic susceptibility testing of the isolates are the best guide in choosing the appropriate antimicrobial therapy in treating puerperal sepsis.

Funding: No funding sources Conflict of interest: None declared

Ethical approval: The study was approved by the Institutional Ethics Committee

\section{REFERENCES}

1. Maharaj D. Puerperal pyrexia; a review. Part II. Obstet Gynecol Surv. 2007;62(6):400-6.

2. Kumar R, Sharma AK, Barik S, Kumar V. Maternal mortality inquiry in a rural community of north India. Int J Gynaecol Obstet. 1989;29:313-9.

3. Bava AK, Khyati P, Nandanwar Ys. Obstetric Hysterectomy Following Post Caesarean Section 
Puerperal Sepsis. Bombay Hospital Journal. 2009;51:273-4.

4. Farrell SJ, Andersen HF, Work BA. Cesarean section: indications and postoperative morbidity. Obstet Gynecol. 1980;56:696.

5. Daftary SN, Chakravarti S. Obstetric shock. Manual of Obstetric, 2nd Edition; Elsevier publisher. 2005.

6. Collee JG, Miles RS, Watt B. Tests for the identification of bacteria. In: Collee J G, Marmion B P, Fraser A G, Simmons A. Mackie \& McCartney Practical Medical Microbiology. Fourteenth edition. Philadelphia: Churchill Livingstone. 1996:131-49.

7. Naheed T, Akbar N. Patients with postpartum complications admitted in a Medical ward of Mayo Hospital, Lahore, Pakistan. J Med Sc. 2002;18(2):126-30.

8. Chaisilwatana P, Roongpisuthipong A. Causative organisms in puerperal sepsis. J Med Assoc Th. 1991;74(3):159-61.

9. Rao K, Ramji S, Thirupuram S, Prakash K. Clinical and bacteriological study of normal and inflamed neonatal conjunctiva. Indian Pediatr. 1992;29:161-5.

10. Kerur BM, Batt BV, Harish BN, Habeebullah S, Kumar CU. Maternal genital bacteria and surface colonization in early neonatal sepsis. Indian J Pediatr. 2006;73(1):29-32.

11. Venugopal MS, Bhaskaran CS. Puerperal and postabortal sepsis (a bacteriological study). J Obstet Gynaecol India. 1968;18(1):70-8.

12. Omu AE, Ajabor LN. Contribution of endotoxic shock to gynecological and maternal morbidity and mortality. J Obstet Gynaecol East Cent Africa. $1983 ; 2(1): 41-5$.
13. Baker JN. Study of cases of puerperal pyrexia in a tertiary level hospital. [Dissertation] Dhaka, Bangladesh: Sir Salimullah Medical College and Mitford hospital. 2005:34.

14. Decherny AH, Nathan L. Postpartum hemorrhage and the abnormal puerperium In: Current Obstetrics and Gynecologic diagnosis and treatment, 9th ed. UK: Prentice Hall International Inc. 2003:531-52.

15. Gerstner G, Leodolter S, Rotter M. Endometrial bacteriology in puerperal infections. Z. Geburtshilfe Perinatol. 1981;185(5):276-9.

16. Newsom Sw. Pioneers in infection control. Ignaz Philip Semmelweis. J Hosp Infect. 1993;23:175-87.

17. Kankuris KOE, Kurkitatio T, Carison T, Esmaa HM. Incidence, treatment and outcome of peripartum sepsis. Acta Obstet Gynecol Scan. 2003;82(8):730-5.

18. Pokharel MS. Study on antibiotic sensitivity pattern of bacterial flora in cases of pre-labor rupture of membranes. [Dissertation] Kathmandu, Nepal: Tribhuvan University. 2004:108.

19. Modi S, Kar J, Gupta. Puerperal sepsis. Cur Med Pract. 1986;30(12):301-6.

20. Martens MG, Faro S, Maccato M, Riddlw G, Hammill HA. Susceptibility of female pelvic pathogens to oral antibiotic agents in patients who develop postpartum Endometritis. AM J Obstet Gynecol. 1991;164:1383-6.

Cite this article as: Tamboli SS, Tamboli SB, Shrikhande S. Puerperal sepsis: predominant organisms and their antibiotic sensitivity pattern. Int J Reprod Contracept Obstet Gynecol 2016;5:762-5. 